\title{
The trends and outcomes of flipped learning research between 2012 and 2018: A descriptive content analysis
}

\author{
Bengi Birgili ${ }^{1,4}\left(\mathbb{C} \cdot\right.$ Fatma Nevra Seggie $^{2} \cdot$ Ebru Oğuz $^{3}$
}

Received: 29 April 2020 / Revised: 11 January 2021 / Accepted: 19 January 2021 /

Published online: 9 February 2021

(C) Beijing Normal University 2021

\begin{abstract}
As an innovative active learning method, flipped learning provides students with several opportunities. This study was conducted to reveal the trends and outcomes in research into the flipped learning approach published between 2012 and 2018. Descriptive content analysis was used to review 316 research and conceptual articles published in academic journals included in five significant databases that ascribe to journals the highest impact factor. The results indicate that most of the studies are conducted with students as the most frequent study group and with a mixed-method research design in the subject areas of education and medicine. The flipped learning approach is mostly conducted in higher education. As a region, Asia has taken the lead in flipped learning studies. Finally, the outcomes of flipped learning indicate an increase in student performance and positive influence on cognitive, affective, and soft skills.
\end{abstract}

Keywords Active learning · Descriptive content analysis · Flipped learning · Student performance

Bengi Birgili

birgilib@mef.edu.tr

Fatma Nevra Seggie

nevra.seggie@boun.edu.tr

Ebru Oğuz

ebru.oguz@msgsu.edu.tr

1 Department of Mathematics and Science Education, MEF University, Istanbul, Turkey

2 Department of Educational Sciences, Boğazici University, Istanbul, Turkey

3 Department of Educational Sciences, Mimar Sinan Fine Arts University, Istanbul, Turkey

4 MEF University, Huzur mah, Maslak Ayazağa cad. No:4, 34396 Maslak-Sarıyer/Istanbul, Turkey 


\section{Introduction}

Communication, teamwork, problem-solving, creativity, and critical thinking are fundamental competencies for achievement in the twenty-first century (Chan et al. 2017). Today's students, who are digital natives, have to be equipped with relevant competencies to respond to the demands of the modern world. For this reason, innovations in teaching-learning processes and instructional environments, which are essential to meet the needs of these learners, have brought active-learning pedagogy to the forefront of education.

Active learning is necessary for students to take part in the learning process and to make their learning permanent (Canaleta et al. 2014; Niemi et al. 2016). An important constraint of education is that teachers cannot simply transmit knowledge to students; rather students need to construct knowledge actively in their own minds (Olusegun 2015; Thompson 2013). "The recent constructivist learning theories emphasize learners' active contribution and self-regulative processes. Active learners have a high level of inquiry skills, and they construct their knowledge base by continuously learning, reflecting on, and controlling their own learning processes (e.g., Pintrich and McKeachie 2000)" (Niemi and Nevgi 2014 , p. 134). Moreover, as a result of the evolution of knowledge, professional life requires learners to become life-long learners (Niemi and Nevgi 2014; Niemi et al. 2016). Active learning strategies, including independent questioning and the constructing of knowledge, emphasize constructivist qualities in knowledge processing, problem-solving action, and critical thinking, and this processing of knowledge results in an accommodation of knowledge (Jang and Kim 2004; Niemi 2002).

With recent developments in active-learning pedagogical approaches and advances in instructional design and technology, some educators encourage the implementation of an active and innovative educational model called flipped learning (Bergmann and Sams 2012, 2014; Lopes and Soares 2018; Sletten 2017). Flipped learning establishes a novel framework within which students are provided with personalized education appropriate for individual learning needs (Bergmann and Sams 2012). The philosophy behind this approach is a sub-type of blended learning, bringing together the learning theories of behaviorism, cognitivism, social learning theory, constructivism, and connectivism. The course learning outcomes rely on Bloom's taxonomy of learning (Bloom et al. 1956; MEF University 2015; Mennella 2016). These theories can be applied in different active learning experiences in a flipped learning environment and depends on the role of students, the role of the instructor, the use of technologies, the need for interaction and collaboration, key elements in online environment design, the need for learner training, key classroom elements, and the need for feedback (Şahin and Fell-Kurban 2016, p. 47). The students can, for example, have the opportunity to watch the videos when they need at their own pace, so their performances are reinforced. During active participation, students can socialize with their classmates and the instructor. The interaction between students during socialization can boost their performance, their collaboration skills, and 
motivation. In addition, in line with cognitivism, students can enhance their procedural knowledge into declarative knowledge such that the previous knowledge gained in a pre-class activity affects the new higher order skills they gain in inclass activities (MEF University 2015; Şahin and Fell-Kurban 2016, 2019).

The implementation of a flipped learning approach can take advantage of the increased occasions for constructivist teaching and learning that technology provides (Koohddang et al. 2009). Flipped learning has many potential benefits including more one-on-one interaction time between teacher and students, active learning and cooperation, and self-paced learning. Also, it provides students with flexibility in the event that they miss some lectures. In addition, flipped learning can be considered complimentary to the traditional classroom setting because it encourages classroom time to be arranged more toward active and collaborative learning (Roach 2014).

In recent years, flipped learning has been introduced to foster active learning in diverse educational contexts, including K-12 and higher education (Şahin and Fell-Kurban 2016; Hamdan et al. 2013). Since its first appearance in the classroom, discussions have frequently focused on the extent to which it is effective in student achievement. Studies have been conducted to determine its effectiveness in this area (Chao et al. 2015; Davis et al. 2013; Hwang and Lai 2017; Mennella 2016; Gomez-Tejedor et al. 2020; Zainuddin and Halili 2016) and to determine the quality of interaction between students, teachers, and the content of lessons (Christiansen et al. 2017; Yildiz-Durak 2018; Winter 2018). Other studies have examined the relationship between student perception and achievement, while prediction studies have focused on the outcomes of academic achievement (Sletten 2017). In line with these findings, our aim is to analyze previous studies on the flipped learning approach in general and their methodologies and results in particular to highlight the trends and outcomes of flipped learning research.

With the accumulated body of literature, we seek to answer the following two main research questions:

1. What are the trends of flipped learning research between 2012 and 2018 in terms of: (a) research design, (b) subject area, (c) age, (d) educational stages (primary, secondary, and higher education), (e) geographic region, and (f) study group?

2. What are the outcomes of flipped learning research between 2012 and 2018 in terms of student learning?

To answer these questions, we first review the literature on flipped learning, highlight important topics in the literature, and discuss the strengths of existing research and specific areas for development. In addition, we elaborate on how flipped learning is related to active learning environments and student learning. 


\section{Literature review}

\section{Flipped learning as a global movement}

Flipped learning, as a general model, is a framework that empowers instructors to reach every student in their teaching and learning processes (Bergmann 2018). Flipped learning allows educators to modify their traditional classroom environment so as to introduce course content and basic learning attainments to learners before meeting in class and to use class time to guide each student with active learning experiences (Sams and Bergmann 2013). This approach helps educators to reconsider their roles and those of their learners for the efficient use of instructional time through interaction. As a teaching approach, flipped learning also provides an opportunity to transform the basic traditional teaching method that places teachers at the center of the learning experience. Outside class, educators provide basic instruction via videos, allowing them to make the best use of time in class by applying a wide range of active learning strategies, methods, and techniques (Bergmann and Sams 2012, 2014; Bergmann 2018; Reidsema et al. 2017; Fell-Kurban 2019; Şahin and Fell-Kurban 2016; Zhan et al. 2017).

Flipped learning was pioneered in 2012 by John Bergmann and Aeron Sams who are both high-school chemistry teachers. They had coined the term "flipped classroom" in 2002 and the term has since gained widespread use. They initially designed this approach for students who miss classes. In 2016, a global coalition of educators, scholars, researchers, practitioners, technologists, and leaders in flipped learning formed the Flipped Learning Global Initiative (FLGI). The organization supports the adoption of flipped learning worldwide, including in the USA, the UK, Taiwan, China, Turkey, the UAE, Spain, and Italy (FLGI 2018a; McCarthy 2016). The launch of the FLGI contributed to the replacement of the popular term "flipped classroom" with "flipped learning" to reflect an expanded understanding of this approach as one that serves an environment-independent teaching rather than just a means of class organization.

Since its first implementation in K-12 schools by Bergmann and Sams, Eric Mazur, a professor at Harvard University, has worked to popularize flipped learning in higher education. The approach and the proposed framework are gaining worldwide recognition as useful in subject areas such as science, medicine, engineering, mathematics, education, literature, and law (Bergmann and Sams 2012, 2014; Bergmann 2018; Lin et al. 2019). Higher education institutions such as Harvard and Stanford in the USA and the first fully flipped university, MEF University in Turkey, have become pioneers of this global movement in the context of tertiary education (FLGI 2018b; Şahin and Fell-Kurban 2016).

One reason for this trend being quickly adopted is that the knowledge of the discipline is easily integrated with active learning environments (Hwang et al. 2015). Universities wishing to use the flipped learning approach have adopted the model with relative ease as it can be integrated into existing teaching and learning systems in a systematic way without the need to rebuild an institution's culture and organizational structure. To facilitate the spread of the flipped learning 
approach worldwide with the best practices and technologies, universities such as Harvard, Stanford and MEF have collaborated in setting out 187 standards. In November 2018, these standards were made public at the Flipped Learning 3.0 Global Standards Summit at MEF University (Flipped Learning 3.0 Global Standards Summit 2018). This summit established an understanding that flipped learning is more than simply uploading lecture recordings, as was simplistically believed in the past (Sams and Bergmann 2013). In the process of flipped learning, learners encounter the course content or outline for the first time via a short video. They complete some preliminary course objectives online and complete a learning activity aligned with class objectives. Learners can thus learn high-level course topics and engage with the instructor and peers by being fully active in the learning environment.

\section{The benefits and drawbacks of flipped learning}

As an emerging teaching and learning model in the educational context, flipped learning presents several advantages and some drawbacks. As for the benefits, the approach allows the presentation of new material before meeting in class, thus preparing students for the in-class teaching and learning process (Crouch and Mazur 2001). As such, it fosters a more productive relationship between instructors and students (McCarthy 2016) where students can learn at their own pace (Molnar 2017) and take responsibility for their own learning (Kim et al. 2017). The approach also provides teachers the opportunity to select from a large pool of learning activities such as mastery learning (Bloom 1968), peer instruction (Mazur 1997), cooperative learning (White and Frederiksen 1998), role-playing (Van Ments 1999), inquirybased learning (Prince and Vigeant 2006), and 5-E strategy (Hew et al. 2018).

Numerous studies of learning outcomes in flipped learning have helped us understand its effectiveness and advocated its benefits. All the academic work conducted over the years has shown that flipped learning has a positive effect on students' learning outcomes, success, and/or academic achievement (see Oh et al. 2017; Tsai et al. 2017 for detail). Based on the literature and practices, our research begins with the assumption that flipped learning positively affects learning outcomes.

Besides the benefits, there are also some drawbacks to this approach. One is the quality of the videos. When these are too long and include several goals, they distort the purpose of the "one video-one goal" concept, leading to a lack of clarity and confusion (Brame 2016). Another challenge is that older learners seem to resist the use of the flipped learning approach (Hewitt 2017; Quarato 2016). In addition, if students come to class unprepared without having watched the video, instructors cannot proceed with the course as planned (Bognar et al. 2018) or students cannot follow the coursework presented to them in class (Heo and Chun 2018). Finally, weekly course video preparation can be demanding for instructors and thus result in videos that can be unattractive to the students (Nielsen 2011). For example, Harrison et al. (2016) used a mixed-method design with 59 engineering students as research participants. The findings reveal that, probably because of poor video usage by the learners, there was a marginally significant negative effect in attending the 
hybrid-flipped learning environment on the total course score as well as a negative effect on homework performance. While flipped learning is an effective approach for students' learning outcomes, instructors cannot be sure that students will watch all the videos before attending class. Poor video viewing rates may be due to the quality of the video content. Any tendency of learners to refuse to take part in lesson preparation, may result in a negative effect on their academic performance (FidalgoBlanco et al. 2017; Harrison et al. 2016).

\section{Flipped learning approach as part of an active learning environment}

The term "flipped classroom" was used until 2012 in reference to both active and passive instructional experiences. It was understood as a classroom type or model which many scholars (Bristol 2014) and even founders (Sams 2011) envisioned as an effective student-centered classroom characterized by the replacement of in-class lectures with co-curricular activities and by the facilitation of students' ability to access their course materials outside of class (Bergmann and Sams 2012; Thongkoo et al. 2019a). In other words, flipped learning started out as a classroom model. However, upon the increase of the acceptance of the model in various proceedings and abstracts (Karariga and Knox 2012; Parslow 2012; Thoms 2012), in a second wave of interest it transitioned into the flipped learning approach. This approach is now considered a comprehensive pedagogical approach involving interactive, higher order activities and thinking processes. Active learning is at its center owing to the interaction between teacher-student, student-student, and even student-content (Thongkoo et al. 2019a, b).

Active learning is a "Grand Meta Principle" within the flipped learning framework (Barkley 2009; Bergmann 2018). Class time is commonly used as a resource for putting active experiences into the hands of students, allowing their minds to be constantly engaged (Prince 2004; Silberman 1996). Flipped learning is, therefore, seen as a learning approach that promotes active engagement (Bond 2020). After watching online pre-learning course videos or doing assignments during their individual work time, learners experience active learning sessions in their classrooms. During these facilitated active learning experiences, they have the opportunity to conduct research, reflect, inquire, test their hypotheses and beliefs, draw conclusions, lead discussions, and give counterexamples. They are involved in hands-on activities; hence, their cognitive performance is higher (Bergmann and Sams 2012, 2014).

Educators use classrooms or learning environments to lead each learner through interactive and innovative experiences of course content using contemporary tools and technologies. During their courses, learners not only remember and understand the content but also apply, analyze, evaluate, and create it (Krathwohl 2002). For example, students can investigate an authentic problem or a real-world challenge with a blend of project-based learning and the flipped approach (Niemi 2002). The aim is to enrich the learning experience by engaging learners in understanding the problem, providing solutions, and designing and creating a model. This enriched experience is geared to 
promote higher order skills (Chi 2009). They are challenged by thinking more critically and deeply so that they are able to make connections between old and new knowledge.

\section{Flipped learning: with or without technology}

The flipped learning approach transforms the classroom into an interactive platform where information is transformed into knowledge and experience. Students have an opportunity to participate actively in the course and to transform the information into knowledge in a process facilitated by the instructor. That is to say, while the student is taught in the traditional teaching method, s/he learns in this approach. This active learning approach is expected to be positively reflected in extra-curricular activities. The aim is to enable students to receive an education that prioritizes their entrepreneurial, innovative thinking, and creativity skills. To achieve this purpose, digital technologies, which increasingly affect all areas of our life, are also used in the planning and execution of educational processes (Sargent and Casey 2020; Zeybek 2020).

Flipped learning cannot be imagined without the use of technology. In every flipped learning approach, technology has to be integrated into teaching and learning activities. Internet technology is recasting education. Massive open online platforms offering courses such as Coursera, edX, Udemy or learning management systems such as Blackboard have facilitated the application of flipped learning to remote learning. Before 2012, while the idea of flipped learning was limited to the idea of the "flipped classroom", technology was an independent tool that could be integrated into education. By contrast, it is now an essential milieu of this pedagogical approach. Video or Web 2.0 tools can be integrated into flipped learning. Teachers, professors, and other educators now apply emerging technologies developed by others.

Thus, flipped learning is an approach that integrates technology in varying degrees to enhance the learning experience. For example, an analysis of 316 papers used in this study to highlight trends and outcomes of research into the flipped learning approach shows the number of the studies that used several technological tools to support flipped learning in 2012-2018 (see Fig. 1). The distribution of technologies referred to in the research papers lends itself to the following categories: MOOC (e.g., Coursera, Udemy, edX, Courseware, MIT); video (e.g., YouTube, TED-Ed, Khan Academy, video lectures, Vodecast, animation); learning management systems [LMS] (e.g., Moodle, Blackboard, Desire2Learn, iLearn); Web 2.0 Tools (e.g., EDpuzzle, Kahoot!, Scratch, Google Forms, Padlet, Online Quiz); audio recordings (e.g., podcasts); social media (e.g., Facebook, Twitter); learning labs (e.g., E-book, Cengage, Pearson Learning Catalytics, eXeCute); video conference tools (e.g., Zoom, Skype); CD, DVD, CD-ROM; simulations (e.g., simulator models); and no information in which the papers did not specify the tools.

\section{The rationale for a comprehensive review of studies on the flipped learning approach and the significance of this study}

Research on the growth of flipped learning, the "flipped" or "inverted" classroom, has been conducted since 2011, but Talbert defined the studies from 2000 to 2013 as 


\section{Technologies used in Flipped Learning}

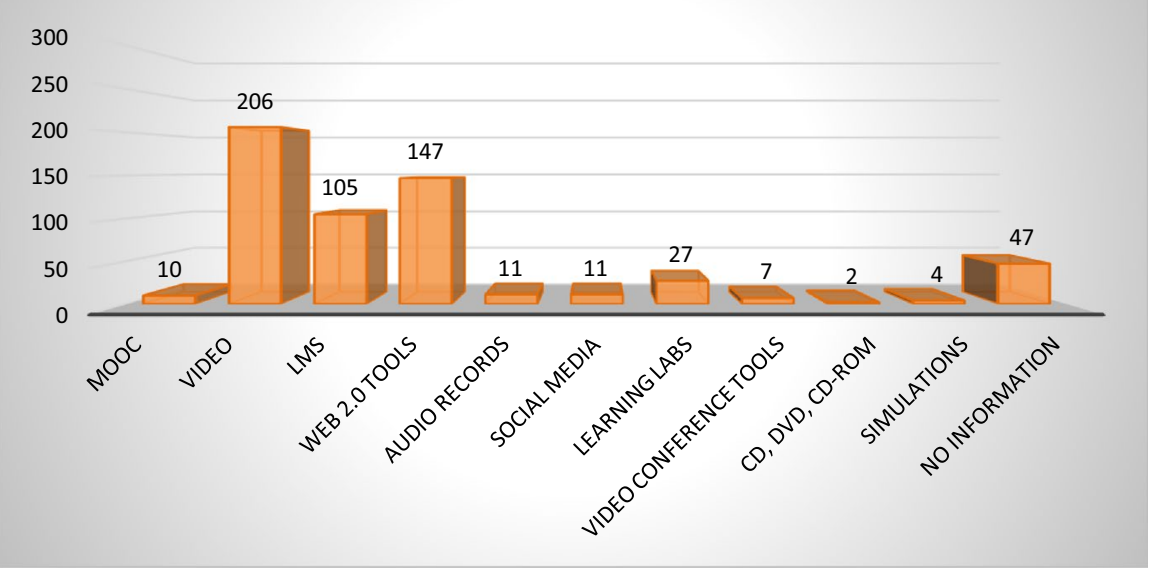

Fig. 1 Distribution of the technologies used in Flipped Learning in 2012-2018

Number of peer-reviewed articles on flipped learning-related research, 2000-2016

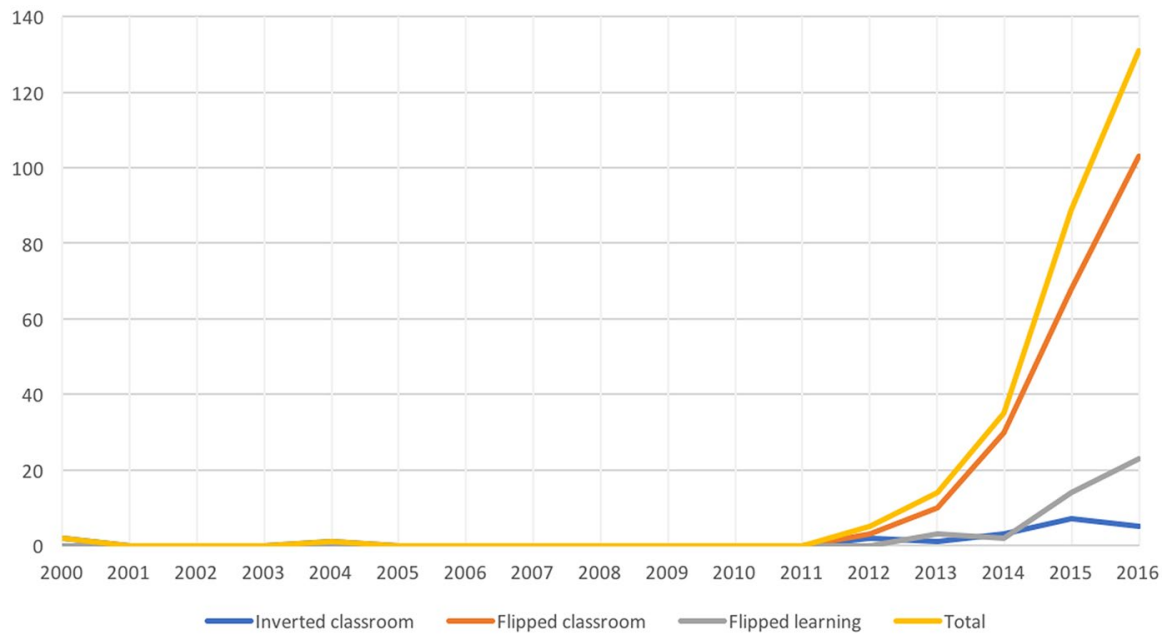

Fig. 2 Growth of flipped learning research (Talbert 2017 p. 2)

flipped learning studies (Talbert 2017). Based on Fig. 2, in our study, we accept the year in which the concept of flipped learning was used as 2012.

Although flipped learning has spread throughout the world exponentially in the last 17 years (see Fig. 2), no consensus has been established between first-hand practitioners on many aspects of this approach (Hew and Lo 2018; Tucker 2012; 
Winter 2018) and hence there are different forms of practice (Bristol 2014; Brown 2016; Kardaş and Yeşilyaprak 2015). Some scholars have explained that literature reviews of flipped learning models had failed to reach a consensus on the definition of the term "flipped learning." For instance, clichés such as "school work at home and home work at school" (Lage et al. 2000, p. 32), "videos at home", and it is "all about watching videos at home and then doing worksheets in class" do not involve the sufficient range of flipped learning approaches. Some have proposed (Bergmann and Sams 2012; O'Flaherty and Phillips 2015) that flipped learning is a type of individualized learning method in which differentiated instruction, inquiry-based learning, and demonstrations are some of the practical strategies.

The practices and experiences of educators using the flipped approach, together with the growing volume of relevant literature, indicate an increasingly widespread embrace of the use of flipped learning in teaching and learning situations. Metaanalysis studies, meta-synthesis, narrative reviews, and descriptive content analysis studies are important to understand the outcomes of the flipped learning approach in terms of student achievement and effective learning. The purpose of this study, therefore, is to explore the trends and outcomes of the flipped learning approach to identify any gaps in the related literature and determine the extent of its utility. This exploration also will help researchers to identify gaps in the literature and enable instructors and administrators to intervene in areas that require further development of the model in a more effective way.

Some systematic review studies (Akçayır and Akçayır 2018; Bond 2020; Låg and Sæle 2019; Lo and Hew 2017; O'Flaherty and Phillips 2015; Turan and AkdagCimen 2020; Zainuddin et al. 2019a, b; Zou et al. 2020) collate and highlight the results of primary studies on the effectiveness of flipped learning on academic performance, student or staff satisfaction, level of engagement, active instructional strategies, and possible challenges. However, some of these reviews include studies with relatively short publication date coverage. For example, Akçayır and Akçayır's (2018) study is limited in its publication date coverage (covering only 2 years) and scrutinized a total of 71 full SSCI published articles on the Web of Science database alone while Zainuddin and et al. (2019a) selected 48 articles published between 2017 and 2018 as samples. In addition, other reviews include articles that are limited in terms of variables as their unit of analysis focusing only on one learner type, one academic discipline, or one education level. For instance, O'Flaherty and Phillips (2015) selected 28 publications between 1994 and 2014, written in English peerreviewed journals, and conducted only at the level of higher education.

In contrast to these review studies, the current study aimed to analyze the trend of flipped learning with several variables as units of analysis and a longer publication date coverage. This type of review will help us to map the effect of the flipped learning approach from different perspectives and construct a big picture with relation to numerous variables.

Moreover, whereas some previous studies review only one discipline and one learner group that might be advantageous for being highly focused in the flipped learning era, we felt it essential to review papers with different variables and thus consider 316 papers. However, we did not aim solely to look at its advantages in a particular area of education, for example medicine or engineering; we considered 
the scope and variables to highlight the general trends of flipped learning. In addition, we tried to determine at what educational level flipped learning provides benefits. We investigated to what extent it is used for each type of learning group rather than a single group of learners and searched for the most preferred educational level. Most importantly, we looked at how flipped learning plays a role as an educational tool. Hence, we are able to identify the gaps in the literature and areas that need further investigation.

In this study, we reviewed articles indexed in five high-factor databases together with the Social Sciences Citation Indexed (SSCI) journals (Clarivate Analytics 2020). By analyzing more studies with wider time intervals, such as between 2012 and 2018, we explored studies from across the globe using six variables (research design, subject area, age, educational stages, geographic region and study group) to produce a comprehensive review that highlights the trends and outcomes of flipped learning research in English publications around the world.

2012 was a watershed year for flipped learning (Bergmann and Sams 2012; Bond 2020; Talbert 2012, 2017) as this was the point at which it began to be used as an active pedagogy as well as becoming the subject of academic research. Having examined the databases for the publications between 2000 and 2012 (e.g. Web of Science), the abstracts of conference proceedings have been disseminated. A search of the keyword "Flipped Classroom" revealed ten publications, three of which (medicine, biochemistry, pharmacology) were conference proceedings publications and the others were abstracts of proceedings. A search of the keyword "Inverted Classroom" revealed 13 publications, all of which were engineering conference papers and abstracts. Finally, a search of the keyword "Flipped Learning" revealed only one conference summary. The keywords "inverted learning" and "inverted classroom" were not employed in the search as this would make our results incomprehensive due to the fact that after 2012 flipped education began to be considered a pedagogical approach rather than a classroom type.

As reported in other systematic review studies in the related literature, flipped learning was systematically reviewed in five publications of Web of Science Core Collection database in the last 5 years (Bond 2020; Gianoni-Capenakas et al. 2019; Karabulut-Ilgu et al. 2018; Turan and Akdag-Cimen 2020; Voronina et al. 2017; Zou et al. 2020). Two of five publications were analyzed particularly in engineering education: 62 articles were included between 2000 and May 2015 in KarabulutIlgu et al.'s (2018) study, whereas 87 articles were included until 2017 in Voronina et al.'s (2017) study. One publication, Gianoni-Capenakas et al. (2019), conducted a systematic review of the eight qualitative studies on the effectiveness of flipped learning on dentistry students' learning and perceptions. The other two publications, very recent studies, were conducted in English Language Teaching by Turan and Akdag-Cimen (2020) and flipped language classrooms by Zou et al. (2020). Turan and Akdag-Cimen (2020) studied 43 articles taken from 5 databases between 2010 and 2018. They examined the trends in flipped learning in terms of years, research methods, education levels, countries of articles, and the main findings in terms of focusing on basic language skills, advantages and challenges, and effectiveness in English Language Teaching. Zou et al. (2020) studied 34 SSCI articles only from 14 different journals between 2015 and 2019. They examined flipped language 
classrooms in terms of publication year, journal, the target language such as English, Chinese or others, participants' education level, sample size, the learning tools used pre, during, and after class activities, and the effect of flipped learning in terms of learning outcomes such as motivation, engagement, academic performance, etc. Finally, Bond's (2020) systematic review uncovered the effectiveness of flipped learning exclusively on student engagement in K-12. As a comprehensive review study, she reviewed 107 articles from seven databases between 2017 and 2019, including uncategorized articles. She discusses the findings in relation to, study characteristics such as geography, study design, methodological characteristics; how to define student engagement; theoretical frameworks; student dis/engagement and flipped learning in K-12, particularly behavioral dis/engagement, affective dis/ engagement, cognitive dis/engagement.

To sum up, this current study relies on a systematic review focusing on the trends and outcomes of flipped learning research between 2012 and 2018. This study differs from others with its approach that uncovers the demographic trends such as research design, subject area, age, educational stages, geographic region, and study group and the outcomes. Our study is distinguished from others in that, to the current date, it reviews the largest number of articles.

\section{Research methods and procedures}

This study was conducted using descriptive content analysis (Cohen et al. 2007). The data were collected from five databases: Web of Science, Science Direct, ERIC, ProQuest, and Ebsco, which are the most inclusive journals with the highest impact factors (Clarivate Analytics 2020). The initial data included all available publications: 196 in Web of Science, 105 in Science Direct, 157 in ERIC, 146 in Proquest, and 192 in Ebsco. The keywords employed were "flipped learning", "flipped classroom", and "flipped learning approach" in all academic disciplines in K-16 settings beginning from 2012, when the first work on flipped learning was published (Bergmann and Sams 2012), up to and including 2018. The criteria for inclusion are that the studies: (1) focus on flipped learning, (2) were published between 2012 and 2018, (3) were published in English, and (4) cover empirical research published in peer-reviewed journals. Duplications across databases, publications that were not empirical, and publications with inaccessible full articles were excluded. The final data included 316 empirical research articles in their full versions.

To answer the first question and identify the trends of flipped learning research in terms of research design, subject area, age, educational stage (primary, secondary, and higher education), geographic region, and study group, two researchers documented relevant information into a table. Later, the information extrapolated was cross-checked and finalized. The final relevant information was coded into categories for each of the above-mentioned pre-identified groups by two researchers and cross-checked again. The agreement rate between the coders was found to be 92\% (Miles and Huberman 1994).

To answer the second question and identify the outcomes of flipped learning research in terms of student learning, two researchers identified the codes while reading 
each article and found relations between them. Two coders worked independently on the same data. Evaluating the intercoder reliability of a coding frame, the two researchers engaged in an agreement-disagreement discussion. Analyses of the two coders were compared, eliminating 30 irrelevant codes. They then organized the codes into categories and filtered them from 40 to 20 . These 20 categories were then categorized into themes, again after agreement-disagreement discussion. This process resulted in a total of 103 codes, 20 categories, and 5 themes. The agreement rate between the coders was found to be $85 \%$ (Miles and Huberman 1994). To illustrate, during the coding process of the Theme: Increase in Performance, the two coders assigned phrases such as "promote learning capability", "enhance academic experience", "positive impact on students' achievement", "supported effective mathematics teaching", and "significantly higher quiz scores in biology" into a performance category. All phrases related to results of the reviewed studies were extracted and then coded into a group of similar content in a codebook table. Final coding was objectively compared with the two coders and then thematized under the heading of positive influence of flipped learning on students' performance (see 'Part 2: Outcomes in flipped learning research' for detail). The first coder found 142 phrases whereas the second coder found 161 phrases related to achievement, performance, and learning. However, they discovered 19 articles revealed no difference in terms of the effectiveness of flipped learning on performance. Hence, they created a coalition session and agreed on the number and theme of the positive influence of flipped learning on students' performance.

As for the data analysis, to determine the trends in flipped learning research, each article was first coded and then categorized according to its research design (quantitative, qualitative, or mixed-method), subject area (arts, arts and letters, design and architecture, economics and administrative science, education, engineering, medicine, law, and science and applied science), the age of the research participants and their educational stage (primary, secondary, and higher education), the geographic region where the study took place, and target study group (teachers, students). Where the related information was not present in the article, it was labelled as non-categorized.

In relation to the outcomes of flipped learning research, we first screened the findings of the articles and counted the number of times keywords, key phrases, or concepts occurred. These occurrences were coded and categorized according to similarity in meaning. During the categorization stage, the primary investigator and the third investigator reviewed the data independently and came up with their own categorizations. After the comparison of the categories, revisions were made and groupings were finalized. This helped to ensure the reliability of the categories. As a result, five themes emerged.

\section{Findings}

This section is divided into two. The first part presents the results related to the first research question, the trends of flipped learning research. In the second part, the results of the outcomes of flipped learning research are documented in terms of the themes that emerged from the data. 


\section{Research Design}

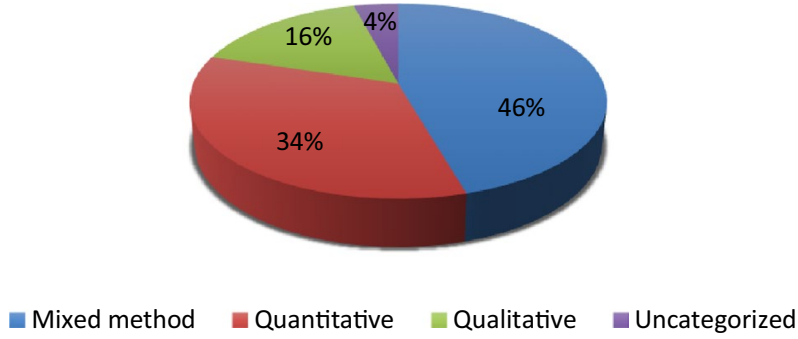

Fig. 3 Distribution of articles by research design

\section{Part 1: trends in flipped learning research}

\section{Research design}

The selected studies mostly utilize a mixed-method research design $(f=144$, around $46 \%)$ and some studies employ a quantitative research design $(f=108$, around $34 \%)$. The least frequently used was a qualitative research design $(f=51$, around $16 \%)$. In addition, around $4 \%$ of the research articles $(f=13)$ did not specify their research design approach (see Fig. 3).

\section{Subject area}

The flipped learning subject areas of the 316 reviewed studies also were examined. The data indicate a wide range of the subject area of each study: (1) education, (2) medicine, (3) engineering, (4) economics, and administrative science, (5) law, (6) arts, design and architecture, (7) science and applied science, (8) arts and letters, and (9) uncategorized.

Most of the research in the reviewed studies was conducted in the fields of education (i.e., teacher education, educational sciences, English language teaching, mathematics education, science education, educational psychology, educational technology) $(f=126,38 \%)$ and medicine (i.e., nursing, dentistry, physiotherapy, pharmacy, adult health) $(f=51,16 \%)$. Flipped learning research studies have also been conducted in the fields of engineering (i.e., biotechnology, big data, computing, robotics) $(f=34,10 \%)$; economics and administrative science (i.e., marketing, business, management, business communication, tourism, project management) $(f=36,11 \%)$; and law $(f=2,1 \%)$. In addition, some of the reviewed studies that rely on the flipped learning approach were conducted in the fields of arts, design and architecture $(f=1,0.3 \%)$; science and applied science (i.e., mathematics, chemistry, science, physics, biology, food science) $(f=44,13 \%)$; arts and letters (i.e., psychology, English, literacy, history, geography, sociology, library) $(f=29,9 \%)$. 


\section{Subject Area}
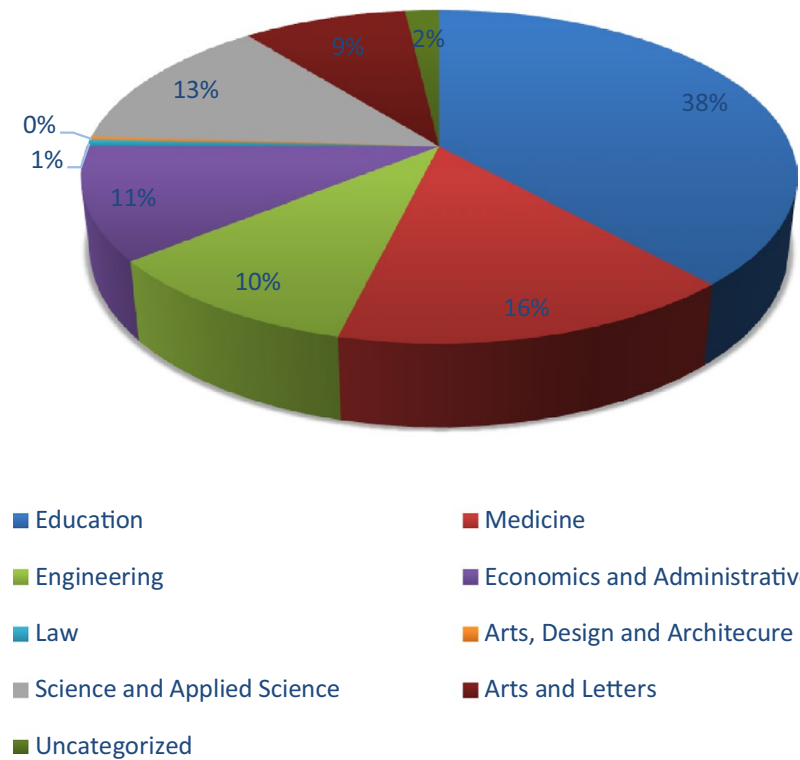

Medicine

- Economics and Administrative Science arts, Design and Architecure

- Arts and Letters

Fig. 4 Distribution of articles by subject area

Finally, some of the reviewed studies were uncategorized $(f=6 ; 2 \%)$ as the research papers did not specify the subject area (see Fig. 4).

Age

The age range of participants cited in the related studies seemed to have a high variability. The researchers, therefore, scattered the data around the frequency rates as follows: participants $(f=95)$ below the age of $10(1 \%), 10-19.5(45 \%)$, 20-29.5 (73\%), 30-39.5 (19\%), 40-49.5 (13\%), and 50+(5\%). These findings show that most participants were aged 20-29.5. Some of the reviewed studies adopting the flipped learning approach were uncategorized as the research papers did not specify the age of the participants $(f=221 ; 70 \%)$ (see Fig. 5).

\section{Educational stage: primary, secondary or higher education}

Concerning the category of educational stage, the studies seemed to be conducted frequently in settings of higher education $(f=268 ; 84 \%)$ while fewer studies were conducted at the primary/preschool $(f=7 ; 2 \%)$ and secondary school $(f=39$; $12 \%)$ levels. A few of the reviewed studies were uncategorized $(f=7 ; 2 \%)$ as the research papers did not specify the educational stage of participants (see Fig. 6). 


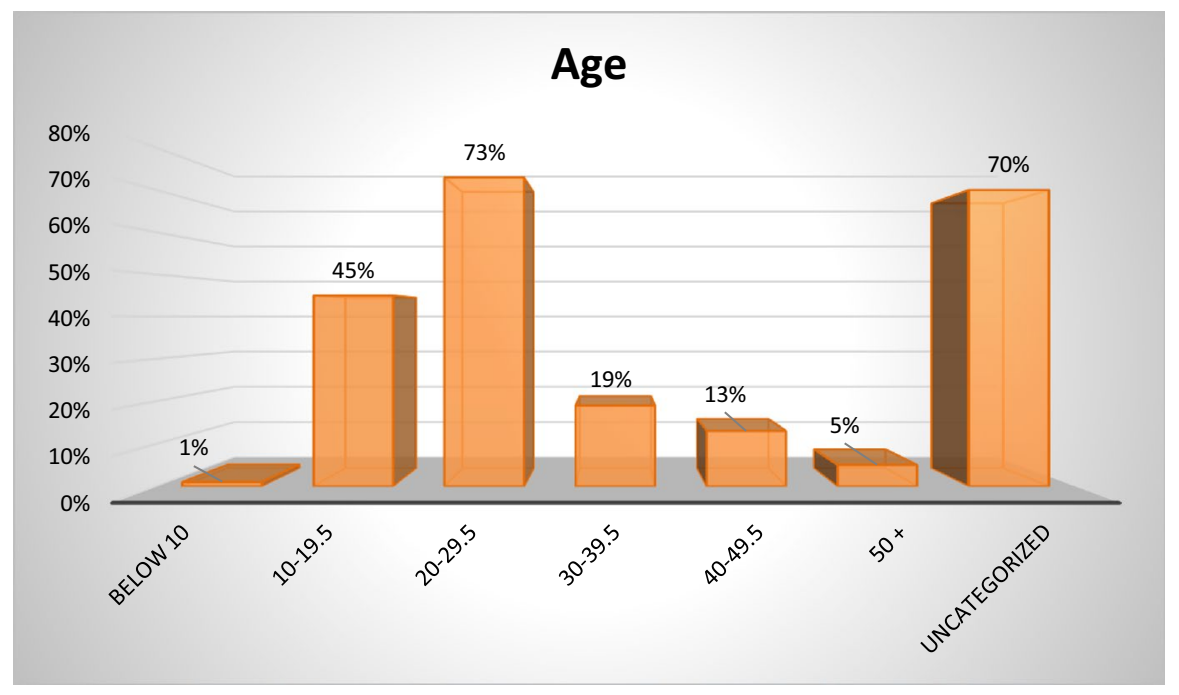

Fig. 5 Distribution of articles by age of participants

\section{Educational Stage}

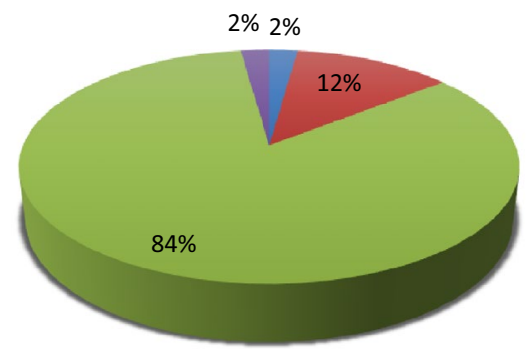

arimary Education $\quad$ Secondary Education $\quad$ Higher Education $\quad$ Uncategorized

Fig. 6 Distribution of articles by educational stage

\section{Geographic region}

Finally, the studies were systematically examined in terms of the continents and countries in which each study was conducted (see Fig. 7). The results show the studies took place largely in Asia, the Americas, Australia, Europe, Eurasia, ${ }^{1}$ and Africa.

To illustrate, Asia $(f=109)$ : Taiwan $(f=31)$, South Korea $(f=27)$, China $(f=15)$; Hong Kong $(f=6)$, Japan $(f=5)$, Malaysia $(f=4)$, Iran $(f=4)$, the UAE $(f=4)$,

\footnotetext{
1 In this study, Eurasia refers to Turkey, Cyprus, and Russia.
} 


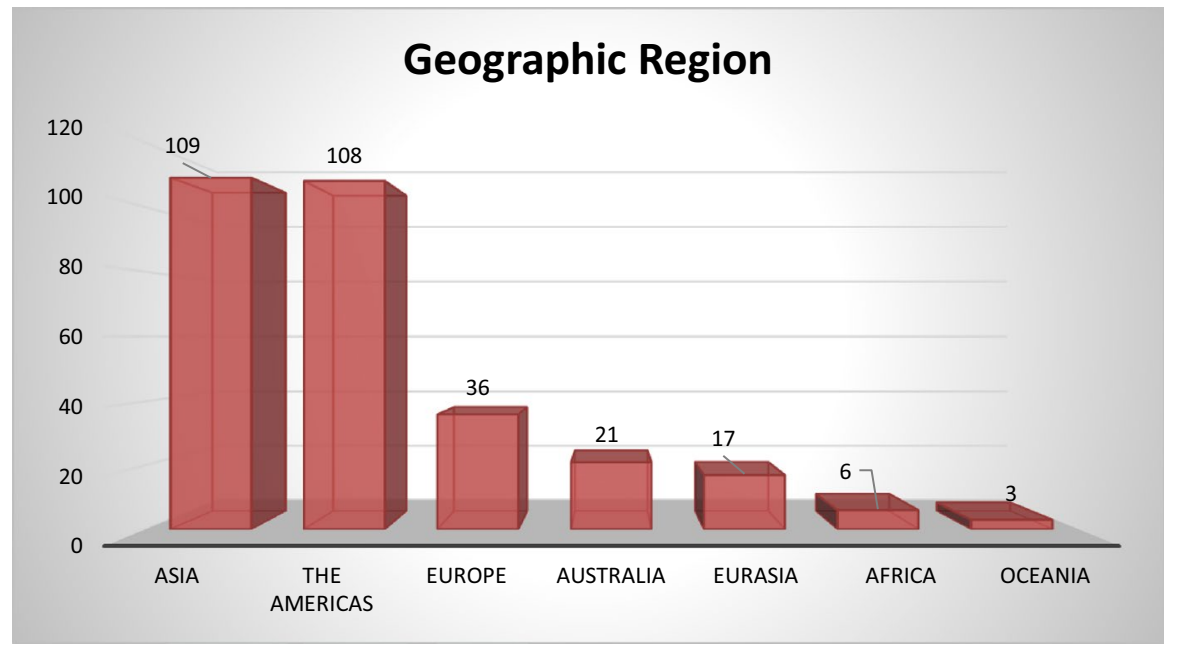

Fig. 7 Distribution of articles by geographic region

Jordan $(f=3)$, India $(f=2)$, Thailand $(f=2)$, Qatar $(f=2)$, Israel $(f=1)$, Lebanon $(f=1)$, Oman $(f=1)$, Vietnam $(f=1)$; the Americas $(f=108)$ : the USA $(f=100)$, Canada $(f=5)$; Jamaica $(f=1)$, Argentina $(f=1)$, Brazil $(f=1)$; Europe $(f=36)$ : the UK $(f=15)$, Spain $(f=6)$, Italy $(f=2)$, Greece $(f=2)$, Ireland $(f=2)$, Sweden $(f=1)$, Denmark $(f=1)$, Northern Macedonia $(f=1)$, the Netherlands $(f=1)$, Norway $(f=1)$, Austria $(f=1)$, Slovenia $(f=1)$, Belgium $(f=1)$, Portugal $(f=1)$; Australia $(f=21)$; and Eurasia $(f=17)$ : Turkey $(f=14)$, the Turkish Republic of Northern Cyprus $(f=2)$ and Russia $(f=1)$; Africa $(f=6)$; Oceania $(f=3)$ : New Zealand $(f=3)$; and Uncategorized $(f=16)$ as the research papers did not specify the geographic region (see Fig. 7).

\section{Study group}

Most of the studies in the literature selected students as participants. Almost $90 \%$ of them used students to do experimental research, correlation research, or to solicit their opinions and perceptions. Only 3\% of the studies, on the other hand, selected teachers as participants. Only one of the studies focused on both teachers and students as the study group (see Fig. 8).

To investigate the outcomes of flipped learning research between 2012 and 2018 in terms of student learning, the researchers employed the content analysis method on the results section of the reviewed studies. The current trend revealed five themes: an increase in student performance, a positive influence on the cognitive domain, a positive influence on the affective domain, a positive influence on soft skills, and flipped learning as an advantageous learning method. These themes are explained (see Fig. 9) in detail. 
Fig. 8 Distribution of articles by study group

\section{Study Group}
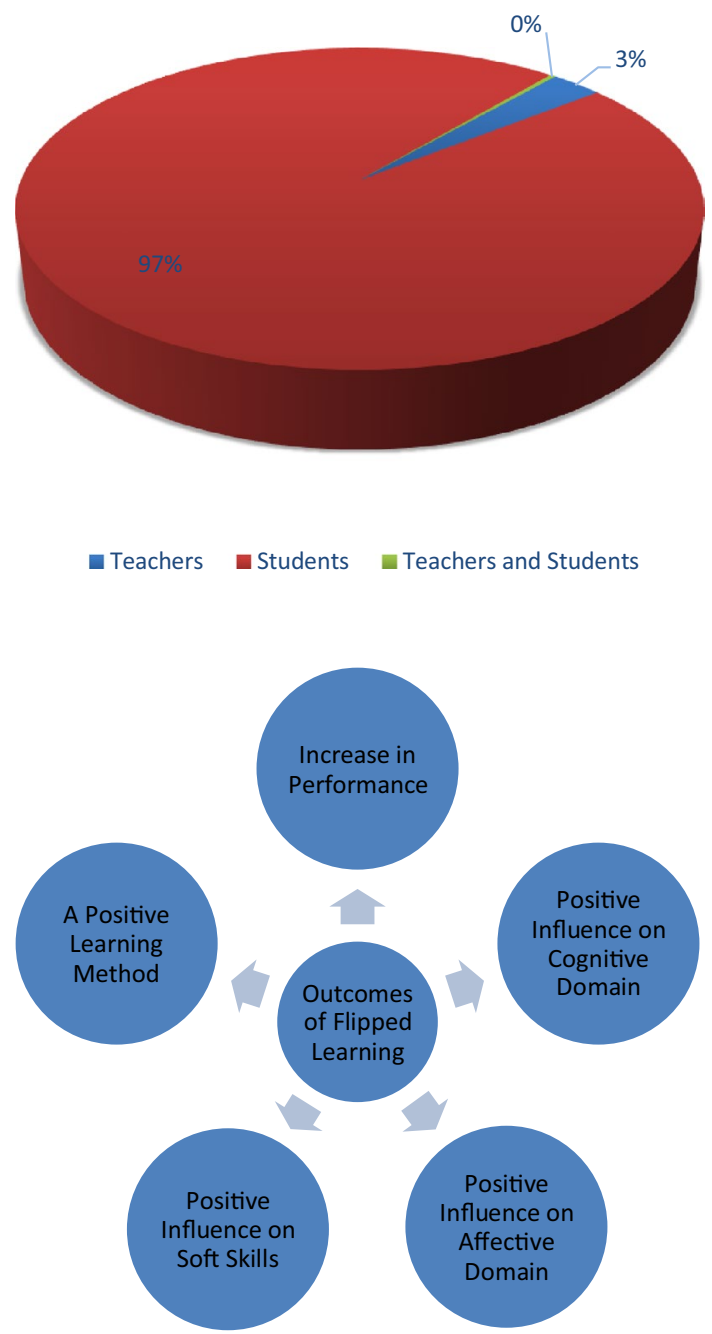

Fig. 9 The themes on outcomes of flipped learning research

\section{Part 2: outcomes in flipped learning research}

Themes: the positive influence of flipped learning on student performance

One hundred and forty-two articles suggest a positive influence of the flipped learning approach on student performance. Some sample categories showing positive influences are as follows: "improvement in learning" (e.g., Deng 2018), "effective blended learning" (e.g., Fadol et al. 2018), "enhancement in learner performance" (e.g., Salem 2018), "advancement in learning skills" (e.g., Shyr and Chen 2018), and "impact on student achievement" (e.g., He et al. 2018). For instance, Lee and 
Wallace (2018) conducted an action research study with 79 students in higher education and divided an English language teaching (ELT) classroom into flipped and non-flipped sections. Their findings demonstrate a difference between the students in the flipped classroom and those in the non-flipped classroom in terms of average course scores in favor of the flipped class, although only the final examination mean score indicated any statistical significance.

To conclude, the content analysis of the results of the related literature show that most of the studies prove that the flipped learning approach is a highly effective teaching method in terms of student performance, academic achievement, and overall learning.

\section{Themes: the positive influence of flipped learning on cognitive domain}

Twenty-two of the articles indicate a positive influence of the flipped learning approach on student cognitive thinking skills. Some sample categories showing positive influences on students' cognitive domain are as follows: "improvement in students' critical thinking skills" (e.g., Dehghanzadeh and Jafaraghaee 2018), "enhancement in higher order thinking skills" (e.g., Hu and Hsu 2018), "contributions to high-level cognitive skills" (e.g., Winter 2018), and "reduction of cognitive load" (e.g., Ponikwer and Patel 2018). To investigate the effects of flipped learning on the cognitive domain, a qualitative case study conducted by Long et al. (2017) in the USA analyzed instructors' experiences and perspectives on using the flipped classroom model in instruction in a higher education institution. Eight faculty members were interviewed and the analysis revealed that flipped learning can provide students with the opportunities for higher order thinking and problem-solving skills.

To conclude, the content analysis of the results of the related literature reveal that 22 studies proved that the flipped learning approach is effective in enhancing students' cognitive thinking skills, promoting higher order thinking and cognitive load, and/or providing flexibility.

\section{Themes: the positive influence of flipped learning on the affective domain}

One hundred and fourteen articles indicate a positive influence on students' affective skills. Some sample categories showing positive influences on students' affective domain are as follows: "facilitation of interactive collaboration", "enhancement of collaborative skills" (e.g., Trust et al. 2018), "positive attitude toward course delivery" (e.g., Bakla 2018), "positive perceptions", "student learning motivation", "higher classroom participation" (e.g., Rodriguez et al. 2018), "an enjoyable academic experience" (e.g., Merlin-Knoblich and Camp 2018), and "improvement in engagement and creativity". An interesting example of such studies occurred in Taiwan, where Bhagat et al. (2016) studied 82 15-year-old secondary school

\footnotetext{
${ }^{2}$ We decided to categorize collaborative skills under the affective domain instead of soft skills because they are the skills which would be intentionally used as an instructional purpose.
} 
mathematics students for 6 weeks. The students were able to ask questions after watching the lesson videos during flipped instruction. The findings indicate not only a significant difference in learning achievement but also in the motivation levels between the two groups of students.

To conclude, the content analysis of the results of the related literature shows that 114 studies revealed that the flipped learning approach enhances students' affective skills such as motivation, engagement, attitude, interest, and enjoyment.

\section{Themes: the positive influence of flipped learning on soft skills}

Thirty-seven of the articles indicate the positive influence of the flipped learning approach on students' soft skills such as "improvement in note-taking ability", "less procrastination", "increased academic identity", "increased ownership of student learning" (e.g., Chivata and Oviedo 2018), "more autonomy and self-directedness" (e.g., Narendran et al. 2018), "enhanced flexibility and interactivity" (e.g., Murray et al. 2017), "improvement in goal setting and self-management skills" (e.g., Çakıroğlu and Öztürk 2017). For example, a UK-based study in medical education was conducted by Gostelow et al. (2018). Two hundred and eighty-nine participants were included in the study. They examined future doctors' clinical practice and attitudinal changes while dealing with global health problems. As a result, it was confirmed that the flipped structure of the learning process increased the students' interaction and flexibility.

\section{Themes: flipped learning as a positive learning method}

Fifty of the articles show flipped learning to be a positive learning method as shown with the follow categories: "increase in positive feedback from instructors", "feedback of the teaching in a positive way" (e.g., Christiansen et al. 2017), "positive feedback toward the methodology and activities" (e.g., Rodriguez 2015), "effective guidance of the pupils", "student preference for the blended learning approach" (e.g., Jarvis et al. 2014), "high student acceptance rate of the learning method", and "high student recognition of the model's advantages" (e.g., Hao 2016). For instance, Caligaris et al. (2016) in Argentina conducted a survey with students to investigate a first practice of flipped classroom with numerical analysis. They questioned the extent to which students benefitted from the flipped learning and were concerned about learning through video-recorded classes. The results indicate students' higher acceptance of the flipped classroom method and satisfaction with the videos.

The content analysis of the results of the related literature show that 50 articles found the flipped learning approach to be a positive learning method. 


\section{Discussion}

The current study aimed to investigate two main research questions: "What were the trends of flipped learning research between 2012 and 2018 in terms of research design, subject area, age, educational stages (primary, secondary, and higher education), geographic region, study group?" and "What were the outcomes of flipped learning research between 2012 and 2018 in terms of student learning?" Our research indicates a consensus that the flipped learning approach increases student achievement and fosters a positive attitude toward learning and motivation. Moreover, it plays an important role in the diversification of teaching methods.

\section{Flipped learning as an effective teaching and learning model}

Flipped learning seems to be used as an effective teaching and learning method increasingly around the globe. As this study shows, the volume of research conducted on flipped learning is growing daily. The findings emphasize that flipped learning helps students learn information more permanently compared to other modes of teaching and that it boosts students' academic performance and overall success. Active learning strategies are among the most efficient ways of facilitating permanent learning in education and in other fields, leading to a new area of exploration in the literature (Zhan et al. 2017).

\section{Trends in flipped learning research}

Most of the research on the flipped learning approach uses a mixed-method research design (Awidi and Paynter 2019; Chang and Hwang 2018; Murphy et al. 2016; Turan and Akdag-Cimen 2020). Using multiple methods of data collection ensures that results are more accurate and comprehensive. Furthermore, the results of the quantitative research methods contribute to the general applicability of the data. The difficulty of conducting qualitative research (Chivata and Oviedo 2018) and of evaluating flipped learning (Pardo and Mirriahi 2017) was also revealed. This difficulty has been observed in studies undertaken first in the fields of applied sciences and education. The studies carried out in the field of healthcare, especially in nursing, prove how effective flipped learning can be in applied sciences. The use of flipped learning in the field of education (e.g., Çukurbaşı and Kıyıcı 2018) and medicine (e.g., Telford and Senior 2017) is more common that than in other disciplines. It is clear that applications in the field of education and medicine should be supported and new applications of flipped learning should be envisioned.

Flipping is a teaching method used mostly in high schools and universities (Turan and Akdag-Cimen 2020; Zou et al. 2020) and most of the studies reviewed here focus on graduate and first-year undergraduate-level students. It is also possible to observe the use of flipped learning with lower levels. Various instructional methods such as problem-based learning and discovery learning are used by teachers concurrently with flipped learning (Namaziandost and Çakmak 
2020). Not only the students but also teachers or pre-service teachers' (e.g., Hao and Lee 2016; Sun et al. 2019) experiences, perceptions, and in-class applications should be scientifically investigated so that gaps in the literature regarding teachers' experiences and perceptions can be filled.

In sum, the current review study shows the trends in flipped learning research preferred using mostly mixed methods followed by quantitative method research design, the majority of the participating students were aged between 20 and 29.5, and their educational stage was mostly higher education followed by secondary education. These findings are in agreement with the results of the study conducted by Turan and Akdag-Cimen (2020). They determined similar trends but only within the scope of ELT flipped classrooms. In addition, Zou et al. (2020) found similar trends in their reviewed studies in flipped language classrooms in general with a study group that was mainly university students (5\% were secondary school students) who wrote frequently in English. Both studies reviewed articles about flipped language classrooms and reached conclusions in boarder perspectives as reported by the trends in the current study. However, those studies examined flipped learning research in English only (Turan and Akdag-Cimen 2020) and in English or Chinese etc. (Zou et al. 2020). Unlike the current study, Zou et al. selected the trends in flipped learning as popular journals flipped learning published, theoretical frameworks and instructional approaches used in the reviewed studies, and video-watching tools and evaluation methods in language classrooms. Further, this current study is distinguished from previous systematic reviews in the literature by the selection of perspectives: subject area, age of the participants, and geographic region.

Most of the scholarship done into flipped learning originates from countries in Asia, followed by those in the Americas and Europe. Considering the recent increase in the success of students in Asian countries on international exams, it could be said that trying different methods of teaching in education could be effective. For example, Hung (2019) explains Taiwan's curricular reform and its effect on decision-making in the classroom. He discusses how self-reflection actively contributes to the structure of teaching style and curricular-instructional decision-making in Taiwan. In addition, learning from the research and practice that is being done by other countries could be instrumental in transforming the cultural structure as well as the education system of a country. We see that flipped learning research is especially widespread in Asia where flipped learning is widely accepted. The leading positions of countries such as Taiwan (e.g., Turan and Akdag-Cimen 2020; Chyr et al. 2018; Wu et al. 2017), China (e.g., Deng 2018; Zhonggen and Liheng 2017), and South Korea (e.g., Choi and Lee 2018; Park and Park 2018) in terms of flipped learning indicates the level to which flipped learning approach is used in these countries. The Americas follows Asia and it is an accepted approach particularly in the leading universities of the USA. We recommend that it be extended to other regions such as Africa and Europe. We also recommend systematic research and dissemination of results in other countries. In addition, it may be insightful to increase the number of studies in which teachers (Zou 2020) are more involved. 


\section{Outcomes in flipped learning research}

Outcomes of the studies highlight the positive effects of the flipped learning model on students' academic and personal skills. We have stated that the flipped learning approach is based on Bloom's taxonomy. The results indicate that flipped learning enables students to reach the dimension of cognitive highlevel thinking skills (Shi et al. 2020). However, further studies need to investigate the attitudes (Birgili et al. 2019) and the psychomotor characteristics of subjects. Some of these findings were pursuant to Bond (2020), Turan and Akdag-Cimen (2020), and Zou et al.'s (2020) systematic review studies. Turan and Akdag-Cimen justify that flipped learning in EFL classrooms help learners to improve overall learning achievement, in particular speaking skills and peer interaction. In addition, Zou et al.'s results also support our outcome suggesting the most important interest in flipped learning studies was students' academic performance. Second, the field was found to be interested in student engagement (see Bond 2020 for detail), motivation, and perceptions about the flipped learning approach (Gianoni-Capenakas et al. 2019; Zou et al. 2020). Six studies investigated the same outcomes in flipped learning as our study. In particular, in their research into academic performance, affective domain and cognitive domain, Zou et al. (2020) suggest that flipped learning has the greatest impact on engagement, a finding that concurs with ours. All in all, the results of our systematic review regarding the positive influence of flipped learning on soft skills and positive learning methods are a contribution to the field.

Furthermore, this study provides an integral overview of the body of research that has been produced since flipped learning was introduced. Students who come to class more prepared are more able to discuss what they have learnt and investigate topics of interest to them, which could increase their motivation to learn. Generation $\mathrm{Z}$ mostly learns using video channels as well as making videos, which could increase the appeal and efficiency of flipped learning. The results of the studies reviewed have also shown that visual aids, such as videos, help students to have an integral outlook as well as increase their commitment to the class and enhance their ability to transfer acquired knowledge to other topics.

Due to the increasing use of technology in every field, especially in education, teaching methods and techniques have changed. Furthermore, these changes have become more prevalent. Making learning more permanent and fun is a result of this evolving teaching philosophy. This unites researchers from different fields in searching for answers as to how learning can be made more permanent. For this purpose, the volume of research on the brain and learning has increased, and the findings of research in neuroscience have been employed in the field of education. The number of studies that focus on how permanent learning and academic success increase when the learner is more active in the learning process is on the rise. This study clearly shows that flipped learning, as an active learning pedagogy, is becoming prevalent in various fields and on various levels. 


\section{Conclusion}

In conclusion, the trend in flipped learning studies suggests that this method is considerably effective. Flipped learning has played an important role in traditional educational methods giving way to non-traditional technology-based methods. Students find active learning pedagogy to be an effective method in the classroom. This method also positively effects students' achievement, attitude, cognitive skills, and soft skills since they take more responsibility for their own learning.

The trend of the studies additionally shows that students are most frequently selected as a study group in the research. To make the flipped learning approach more effective, it is necessary to focus more on the challenges and experiences of the educators. Also, the effect of course videos is an important variable in the success of the flipped learning and success stems from their quality. Thus, more research should be conducted in this area. Additionally, as revealed in the literature, there were some drawbacks regarding flipped learning. More detailed research is required into these areas, in particular into the problems in the preparation of videos.

The effectiveness of flipped learning supports our findings and arguments that not only one or two flipped courses or flipped classrooms but whole flipped schools would be useful for new educational paradigm shifts. Especially in light of recent developments, the hybrid flexible (HyFlex) approach, which is a teaching and learning process that brings together face-to-face and online learning course formats, is poised to become more widespread in the near future.

\section{Limitations and suggestions for further research}

This is a document analysis study which mainly adopts a quantitative approach to the analysis of trends and outcomes of flipped learning research since 2012. The nature and type of publications before 2012 could also be investigated for a greater understanding into the evolution of the flipped learning approach. In addition, only articles accessed in full text were included in the analysis process. Moreover, the research did not include the terms "flipped classroom" and "inverted classroom" studies so the results of these studies were not compared and contrasted. The study was limited to the indexes selected for this study and research articles. Graduate theses were not included in the research. It could be beneficial for future studies to include all these different types of work.

We examined the studies circulated in five high-factor databases. This could be expanded by other indexes in future studies. Books written in the field of flipped learning, proceedings, presentation abstracts, and theses can also be included in the analysis. With the increase in the use of online education due to the onset of the pandemic in 2020, the studies before and after COVID-19 can be compared and the effectiveness of this comparison on flipped learning can be investigated in future studies. 
Acknowledgements The authors would like to thank İsmail Elçiçek and Kübra Demirörs for their assistance during the data collection.

Funding This research did not receive any specific grant from funding agencies in the public, commercial, or not-for-profit sectors.

\section{Compliance with ethical standards}

Conflict of interest None.

\section{References}

Akçayır, G., \& Akçayır, M. (2018). The flipped classroom: A review of its advantages and challenges. Computers \& Education, 126(1), 334-345.

Awidi, I. T., \& Paynter, M. (2019). The impact of a flipped classroom approach on student learning experience. Computers \& Education, 128(1), 269-283.

Bakla, A. (2018). Learner-generated materials in a flipped pronunciation class: Asequential explanatory mixed-methods study. Computers \& Education, 125(1), 14-38.

Barkley, E. (2009). Student engagement techniques: A handbook for college faculty. San Francisco, CA: Jossey-Bass.

Bergmann, J. (2018). "It's time to reach every student." Retrieved from http://flglobal.org/trainingservice $\mathrm{s} /$.

Bergmann, J., \& Sams, A. (2012). Flip your classroom: Reach every student in every class every day. Eugene: ISTE: International Society for Technology in Education.

Bergmann, J., \& Sams, A. (2014). Flipped learning: Gateway to student engagement. Eugene: ISTE: International Society for Technology in Education.

Bhagat, K. K., Chang, C. N., \& Chang, C. Y. (2016). The impact of the flipped classroom on mathematics concept learning in high school. Educational Technology \& Society, 19(3), 134-142.

Birgili, B., Seggie, F. N., \& Kızıltepe, Z. (2019). Investigating the relationship between volitional strategies and academic achievement in a flipped learning environment. Croatian Journal of Education, 21(1), 345-375. https://doi.org/10.15516/cje.v21i1.3006.

Bloom, B. (1968). Learning for mastery: Instruction and curriculum. Chicago, IL: Chicago University Press.

Bloom, B. S. (Ed.), Engelhart, M. D., Furst, E. J., Hill, W. H., \& Krathwohl, D. R. (1956). Taxonomy of educational objectives: The classification of educational goals. Handbook 1: Cognitive domain. New York: David McKay.

Bognar, B., Sablic, M., \& Skugor, A. (2018). Flipped learning and online discussion in higher education teaching. In L. Daniela (Ed.), Didactics of smart pedagogy (pp. 371-392). Cham: Springer Nature.

Bond, M. (2020). Facilitating student engagement through the flipped learning approach in K-12: A systematic review. Computers \& Education. https://doi.org/10.1016/j.compedu.2020.103819.

Brame, C. J. (2016). Effective educational videos: Principles and guidelines for maximizing student learning from video content. CBE Life Sciences Education, 15(4), 1-6.

Bristol, T. J. (2014). Flipping the classroom. Teaching and Learning in Nursing, 9, 43-46.

Brown, B. A. (2016). Understanding the flipped classroom: Types, uses and reactions to a modern and evolving pedagogy. Culminating Projects in Teacher Development, 12. Retrieved from https:// repository.stcloudstate.edu/ed_etds/12.

Çakıroğlu, Ü., \& Öztürk, M. (2017). Flipped classroom with problem-based activities: Exploring selfregulated learning in a programming language course. Educational Technology \& Society, 20(1), 337-349.

Caligaris, M., Rodrígueza, G., \& Laugeroa, L. (2016). A first experience of flipped classroom in numerical analysis. Procedia - Social and Behavioral Sciences, 217(1), 838-845.

Canaleta, X., Vernet, D., Vicent, L., \& Montero, J. A. (2014). Master in teacher training: A real implementation of active learning. Computers in Human Behavior, 31(1), 651-658. 
Chan, C. K. Y., Fong, E. T. Y., Luk, L. Y. Y., \& Ho, R. (2017, November). A review of literature on challenges in the development and implementation of generic competencies in higher education curriculum. International Journal of Educational Development, 57(1), 1-10.

Chang, S.-C., \& Hwang, G.-J. (2018). Impacts of an augmented reality-based flipped learning guiding approach on students' scientific project performance and perceptions. Computers \& Education, 125(1), 226-239.

Chao, C. Y., Chen, Y. T., \& Chuang, K. Y. (2015). Exploring students' learning attitude and achievement in flipped learning supported computer aided design curriculum: A study in high school engineering education. Computer Applications in Engineering Education, 23(4), 514-526.

Chi, M. (2009). Active-constructive-interactive: A conceptual framework for differentiating learning activities. Topics in Cognitive Science, 1(1), 73-105.

Chivata, Y. P., \& Oviedo, R. C. (2018). EFL students' perceptions of activeness during the implementation of flipped learning approach at a Colombian university. Gist Education and Learning Research Journal, 17(1), 81-105.

Choi, J., \& Lee, Y. (2018). To what extent does "flipping" make lessons effective in a multimedia production class? Innovations in Education and Teaching International, 55(1), 3-12.

Christiansen, M. A., Nadelson, L., Etchberger, L. K., Cuch, M. M., Kingsford, T. A., \& Woodward, L. O. (2017). Flipped learning in synchronously-delivered, geographically-dispersed general chemistry classrooms. Chemistry and Biochemistry Faculty Publications. https://doi.org/10.1021/acs.jchem ed.6b00763.

Chyr, W.-L., Shen, P.-D., Chiang, Y.-C., Lin, J.-B., \& Tsai, C.-W. (2018). Exploring the effects of online academic help-seeking and flipped learning on improving students' learning. Journal of Educational Technology \& Society, 20(3), 11-23.

Clarivate Analytics. (2020). Journal Citation Reports. Retrieved from https://jcr.clarivate.com/JCRLa ndingPageAction.action.

Cohen, L., Manion, L., \& Morrison, K. (2007). Research methods in education (6th ed.). New York, NY: Routledge.

Crouch, C., \& Mazur, E. (2001). Peer instruction: Ten years of experience and results. American Journal of Physics, 69(1), 970-977.

Çukurbaşı, B., \& Kıyıcı, M. (2018). Öğretmen adaylarının öğretimde internet teknolojilerini kullanmaya yönelik tercihlerindeki değişimin incelenmesi [An analysis on the change in preferences of preservice teachers towards use of the internet technologies in teaching]. Kastamonu Education Journal, 26(3), 765-776.

Davis, L., Neary, M. A., \& Vaughn, S. E. (2013). Teaching advanced legal research in a flipped classroom. Perspectives: Teaching Legal Research and Writing, 22(1), 13-19.

Dehghanzadeh, S., \& Jafaraghaee, F. (2018). Comparing the effects of traditional lecture and flipped classroom on nursing students' critical thinking disposition: A quasi-experimental study. Nurse Education Today, 71, 151-156.

Deng, L. (2018). The project-based flipped learning model in business English translation course: Learning, teaching and assessment. English Language Teaching, 11(9), 118-128.

Fadol, Y., Aldamen, H., \& Saadullah, S. (2018). A comparative analysis of flipped, online and traditional teaching: A case of female Middle Eastern management students. The International Journal of Management Education, 16(1), 266-280.

Fell-Kurban, C. (2019). Designing effective, contemporary assessment on a flipped educational sciences course. Interactive Learning Environments, 27(8), 1143-1159.

Fidalgo-Blanco, A., Martinez-Nuñez, M., Borrás-Gene, O., \& Sanchez-Medina, J. J. (2017). Micro flip teaching-An innovative model to promote the active involvement of students. Computers in Human Behavior, 72, 713-723.

Gianoni-Capenakas, S., Lagravere, M., Pacheco-Pereira, C., \& Yacyshyn, J. (2019). Effectiveness and perceptions of flipped learning model in dental education: A systematic review. Journal of Dental Education, 83(8), 935-945. https://doi.org/10.21815/JDE.019.109.

Gomez-Tejedor, J. A., Vidaurre, A., Tort-Ausina, I., Molina-Mateo, J., Serrano, M.-A., Meseguer-Duenas, J. M., et al. (2020). Effectiveness of flip teaching on engineering students' performance in the physics lab. Computers \& Education. https://doi.org/10.1016/j.compedu.2019.103708.

Gostelow, N., Barber, J., Gishen, F., \& Berlin, A. (2018). Flipping social determinants on its head: Medical student perspectives on the flipped classroom and simulated patients to teach social determinants of health. Medical Teacher, 40(7), 728-735. 
Hamdan, N., McKnight, P., McKnight, K., \& Arfstrom, K. M. (2013, June). A review of flipped learning. Retrieved from http://www.flippedlearning.org/cms/lib07/VA01923112/Centricity/Domain/41/ LitReview_FlippedLearning.pdf.

Hao, Y. (2016). Exploring undergraduates' perspectives and flipped learning readiness in their flipped classrooms. Computers in Human Behavior, 59(1), 82-92.

Hao, Y., \& Lee, K. S. (2016). Teaching in flipped classrooms: Exploring pre-service teachers' concerns. Computers in Human Behavior, 57, 250-260.

Harrison, D. J., Saito, L., Markee, N., \& Herzog, S. (2016). Assessing the effectiveness of a hybridflipped model of learning on fluid mechanics instruction: Overall course performance, homework, and far- and near-transfer of learning. European Journal of Engineering Education. https://doi. org/10.1080/03043797.2016.1218826.

He, W., Holton, A. J., \& Farkas, G. (2018). Impact of partially flipped instruction on immediate and subsequent course performance in a large undergraduate chemistry course. Computers \& Education, 125, 120-131.

Heo, H. J., \& Chun, B. A. (2018). Improving the higher order thinking skills using flipped learning: Focused on the in-class activities with problem posing and solving. Asia Life Sciences Supplement, 15(4), 2187-2199.

Hew, K. F., \& Lo, C. K. (2018). Flipped classroom improves student learning in health professions education: A meta-analysis. BMC Medical Education, 18(38), 1-12.

Hew, K. F., Zhu, Y., \& Lo, C. K. (2018). Designing and evaluating postgraduate courses based on a 5e-flipped classroom model: A two-case mixed-method study. In S. Cheung, J. Lam, K. Li, O. Au, W. Ma, \& W. Ho (Eds.), Technology in education: Innovative solutions and practices, ICTE 2018. Communications in computer and information science, 843. Singapore: Springer.

Hewitt, L. (2017). Timing is flipping everything: A case study in Law that suggests student engagement depends on when the Flipped Classroom is introduced. Compass: Journal of Learning and Teaching, 10(1), 1-8.

Hu, C.-F., \& Hsu, F.-F. (2018). The value of adding a flipped learning component to a humanities course in higher education: Student perception and performance. Taiwan Journal of TESOL, 15(2), 1-32.

Hung, Y.-H. (2019). To teach or not teach controversial public issues in Taiwan? Asia Pacific Journal of Education. https://doi.org/10.1080/02188791.2019.1671807.

Hwang, G.-J., \& Lai, C.-L. (2017). Facilitating and bridging out-of-class and in-class learning: An interactive e-book-based flipped learning approach for math courses. Educational Technology \& Society, 20(1), 184-197.

Hwang, G.-J., Lai, C.-L., \& Wang, S.-Y. (2015). Seamless flipped learning: A mobile technology enhanced flipped classroom with effective learning strategies. Journal of Computer Education, 2(4), 449-473.

Flipped Learning Global Initiative [FLGI]. (2018a). Available from http://flglobal.org.

Flipped Learning Global Initiative [FLGI]. (2018b). The five qualities of world-class flipped learning practitioners. Retrieved from http://flglobal.org/five-qualities-of-world-class-flipped-learning/.

Jang, S., \& Kim, N. (2004). Transition from high school to higher education and work in Korea, from the competency-based education perspective. International Journal of Educational Development, 24(6), 691-703.

Jarvis, W., Halvorson, W., Sadeque, S., \& Johnston, S. (2014). A large class engagement (lce) model based on service-dominant logic (sdl) and flipped classrooms. Education Research \& Perspectives, 41, 1-24.

Karabulut-Ilgu, A., Jaramillo Cherrez, N., \& Jahren, C. T. (2018). A systematic review of research on the flipped learning method in engineering education. British Journal of Educational Technology, 49(3), 398-411. https://doi.org/10.1111/bjet.12548.

Karariga, I.-R., \& Knox, B. (2012, July). Flipped classroom for professional development. Paper presented at the 4th International Conference on Education and New Learning Technologies (EDULEARN), Barcelona, Spain.

Kardaş, F., \& Yeşilyaprak, B. (2015). A current approach to education: Flipped learning model. Ankara University Journal of Faculty of Educational Sciences, 48(2), 103-121.

Kim, H. S., Kim, M. Y., Cho, M.-K., \& Jang, S. J. (2017). Effectiveness of applying flipped learning to clinical nursing practicums for nursing students in Korea: A randomized controlled trial. International of Journal Nursing Practice, 23(1), 1-10.

Koohang, A., Riley, L., Smith, T., \& Schreurs, J. (2009). E-learning and constructivism: From theory to application. Interdisciplinary Journal of E-Learning Objects, 5(1), 91-109. 
Krathwohl, D. R. (2002). A revision of Bloom's taxonomy: An overview. Theory into Practice, 41(4), 212-264.

Låg, T., \& Sæle, R. G. (2019, July-September). Does the flipped classroom improve student learning and satisfaction? A systematic review and meta-analysis. AERA Open, 5(3), 1-17.

Lage, M. J., Platt, G. J., \& Treglia, M. (2000). Inverting the classroom: A gateway to creating an inclusive learning environment. The Journal of Economic Education, 31(1), 30-43.

Flipped Learning 3.0 Global Standards Summit. (2018). Available from http://aalasinternational.org/flipp ed-learning-global-standards-summit/.

Lee, G., \& Wallace, A. (2018). Flipped learning in the English as a foreign language classroom: Outcomes and perceptions. TESOL Quarterly, 52, 62-84.

Lin, H.-C., Hwang, G.-J., \& Hsu, Y.-D. (2019). Effects of ASQ-based flipped learning on nurse practitioner learners' nursing skills, learning achievement and learning perceptions. Computers \& Education, 139(1), 207-221.

Lo, C. K., \& Hew, K. F. (2017). A critical review of flipped classroom challenges in K-12 education: Possible solutions and recommendations for future research. Research and Practice in Technology Enhanced Learning, 12(4), 1-22.

Long, T., Cummins, J., \& Waugh, M. (2017). Use of the flipped classroom instructional model in higher education: Instructors' perspectives. Journal of Computing in Higher Education, 29(2), 179-200.

Lopes, A. P., \& Soares, F. (2018). Perception and performance in a flipped financial mathematics classroom. The International Journal of Management Education, 16(1), 105-113.

Mazur, E. (1997). Peer instruction: A user's manual. Upper Saddle River, NJ: Prentice Hall.

McCarthy, J. (2016). Reflections on a flipped classroom in first year higher education. Issues in Educational Research, 26(2), 332-350.

MEF University. (2015, October). MEF flipped learning course design policy. Center for Research and Best Practices in Learning and Teaching (CELT), Istanbul, Turkey.

Mennella, T. A. (2016). Comparing the efficacy of flipped vs. alternative active learning in a college genetics course. The American Biology Teacher, 78(6), 471-479.

Merlin-Knoblich, C., \& Camp, A. (2018). A case study exploring students' experiences in a flipped counselling course. Counselor Education \& Supervision, 57, 301-316.

Miles, M. B., \& Huberman, A. M. (1994). Qualitative data analysis: An expanded sourcebook (2nd ed.). Thousand Oaks: Sage Publications.

Molnar, K. K. (2017). What effect does flipping the classroom have on undergraduate student perceptions and grades? Education and Information Technologies, 22(1), 2741-2765.

Murphy, J., Chang, J. M., \& Suaray, K. (2016). Student performance and attitudes in a collaborative and flipped linear algebra course. International Journal of Mathematical Education in Science and Technology, 47(5), 653-673.

Murray, D., McGill, T., Thompson, N., \& Toohey, D. (2017). Can learners become teachers? Evaluating the merits of student generated content and peer assessment. Issues in Informing Science and Information Technology Education, 14, 21-33.

Namaziandost, E., \& Çakmak, F. (2020). An account of EFL learners' self-efficacy and gender in the Flipped Classroom Model. Education and Information Technologies. https://doi.org/10.1007/s1063 9-020-10167-7.

Narendran, R., Almeida, S., Coombes, R., Hardie, G., Quintana-Smark, E., Zaher, N., et al. (2018). The role of self- determination theory in developing curriculum for flipped classroom learning: A case study of first-year business undergraduate course. Journal of University Teaching \& Learning Practice, 15(5), 1-20.

Nielsen, L. (2011). Five Reasons I'm Not Flipping over the Flipped Classroom. Technology \& Learning, Retrieved from https://www.techlearning.com/tl-advisor-blog/3360.

Niemi, H. (2002). Active learning-A cultural change needed in teacher education and in schools. Teaching and Teacher Education, 18(1), 763-780.

Niemi, H., Nevgi, A., \& Aksit, F. (2016). Active learning promoting student teachers' professional competences in Finland and Turkey. European Journal of Teacher Education, 39(4), 471-490. https:// doi.org/10.1080/02619768.2016.1212835.

Niemi, H., \& Nevgi, A. (2014). Research studies and active learning promoting professional competences in Finnish teacher education. Teaching and Teacher Education, 43(1), 131-142.

O'Flaherty, J., \& Phillips, C. (2015). The use of flipped classrooms in higher education: A scoping review. The Internet and Higher Education, 25(1), 85-95. 
Oh, J., Kim, S. J., Kim, S., \& Vasuki, R. (2017). Evaluation of the effects of flipped learning of a nursing informatics course. Journal of Nursing Education, 56(8), 477-483.

Olusegun, S. (2015). Constructivism learning theory: A paradigm for teaching and learning. Journal of Research \& Method in Education (IOSR-JRME), 5(6), 66-70.

Pardo A., \& Mirriahi, N. (2017). Design, deployment and evaluation of a Flipped learning first-year engineering course. In C. Reidsema, L. Kavanagh, R. Hadgraft, \& N. Smith (Eds.), (pp. 177-191). The Flipped classroom. Singapore: Springer.

Park, E. O., \& Park, J. H. (2018). Quasi-experimental study on the effectiveness of a flipped classroom for teaching adult health nursing. Japan Journal of Nursing Science, 15(2), 125-134.

Parslow, G. R. (2012). Commentary: The Khan academy and the day-night flipped classroom. Biochemistry and Molecular Biology Education, 40(5), 337-338.

Pintrich, P. R., \& McKeachie, W. J. (2000). A framework for conceptualizing student motivation and self-regulated learning in the college classroom. In P. R. Pintrich \& P. Ruohotie (Eds.), Conative constructions and self-regulated learning (pp. 31-50). Hameenlinna: RCVE.

Ponikwer, E., \& Patel, B. A. (2018). Implementation and evaluation of flipped learning for delivery of analytical chemistry topics. Analytical and Bioanalytical Chemistry, 410, 2263-2269.

Prince, M. (2004). Does active learning work? A review of the research. Journal of Engineering Education, 93(3), 223-231.

Prince, M., \& Vigeant, M. (2006). Using inquiry-based activities to promote understanding of critical engineering concepts. In ASEE Conference, Chicago, IL.

Quarato, S. (2016). Is the flipped classroom pedagogy effective for all students? Unpublished certificate of advanced study thesis, Sacred Heart University, Fairfield, CT. Retrieved from http://digitalcom mons.sacredheart.edu/ed1/9/.

Reidsema, C., Kavanagh, L., Hadgraft, R., \& Smith, N. (2017). The flipped classroom: Practice and practices in higher education. Singapore: Springer Nature.

Roach, T. (2014). Student perceptions toward flipped learning: New methods to increase interaction and active learning in economics. International Review of Economics Education, 17(1), 74-84.

Rodriguez, R. E. (2015). A massively flipped class: Designing and implementing active learning information literacy instruction for a large enrolment course. Reference Services Review, 44(1), 4-20.

Rodriguez, M., Diaz, I., Gonzalez, E. J., \& González-Miquel, M. (2018). Motivational active learning: An integrated approach to teaching and learning process control. Education for Chemical Engineers, 24(1), 7-12.

Şahin, M., \& Fell-Kurban, K. (2016). The flipped approach to higher education: Designing universities for today's knowledge economies and societies. Bingley: Emerald Publishing.

Şahin, M., \& Fell-Kurban, K. (2019). The new university model: Flipped, adaptive, digital and active Learning (FADAL). Houston: FL Global Publishing.

Salem, A. A. M. S. (2018). Engaging ESP university students in flipped classrooms for developing functional writing skills, hots, and eliminating writer's block. English Language Teaching, 11(12), 177-198.

Sams, A. (2011). The flipped classroom. Paper presented at the Conference 242nd National Meeting of the American-Chemical-Society (ACS), Denver, CO.

Sams, A., \& Bergmann, J. (2013). Flip your students' learning. Educational Leadership, 70(6), 16-20.

Sargent, J., \& Casey, A. (2020). Flipped learning, pedagogy and digital technology: Establishing consistent practice to optimise lesson time. European Physical Education Review, 26(1), 70-84.

Shi, Y., Ma, Y., MacLeod, J., \& Yang, H. H. (2020). College students' cognitive learning outcomes in flipped classroom instruction: A meta-analysis of the empirical literature. Journal of Computers in Education, 7(1), 79-103.

Shyr, W.-J., \& Chen, C.-H. (2018). Designing a technology-enhanced flipped learning system to facilitate students' self-regulation and performance. Journal of Computer Assisted Learning, 34, 53-62.

Silberman, M. (1996). Active learning: 101 strategies to teach any subject. Prentice-Hall, PO Box 11071, Des Moines, IA 50336-1071.

Sletten, S. R. (2017). Investigating flipped learning: Student self-regulated learning, perceptions, and achievement in an introductory biology course. Journal of Science and Educational Technology, 26(1), 347-358.

Sun, F.-R., Hu, H.-Z., Wan, R.-G., Fu, X., \& Wu, S.-J. (2019). A learning analytics approach to investigating pre-service teachers' change of concept of engagement in the flipped classroom. Interactive Learning Environments. https://doi.org/10.1080/10494820.2019.1660996. 
Talbert, R. (2012, June). Learning matlab in the inverted classroom. Paper presented at the ASEE Annual Conference, San Antonio.

Talbert, R. (2017). How much research has been done on flipped learning? An update for mid-2017. Retrieved from http://rtalbert.org/how-much-research-update/.

Telford, M., \& Senior, E. (2017). Healthcare students' experiences when integrating e-learning and flipped classroom instructional approaches. British Journal of Nursing, 26(11), 617-622.

Thompson, P. (2013). Learner-centred education and 'cultural translation.' International Journal of Educational Development, 33(1), 48-58.

Thoms, C. L. V. (2012, November). Enhancing the blended learning curriculum by using the "flipped classroom" approach to produce a dynamic learning environment. Paper presented at the 5th International Conference of Education, Research and Innovation (ICERI), Madrid, Spain.

Thongkoo, K., Panjaburee, P., \& Daungcharone, K. (2019). A development of ubiquitous learning support system based on an enhanced inquiry-based learning approach. International Journal of Mobile Learning and Organisation, 13(2), 129-151.

Thongkoo, K., Panjaburee, P., \& Daungcharone, K. (2019). Integrating inquiry learning and knowledge management into a flipped classroom to improve students' web programming performance in higher education. Knowledge Management \& E-Learning, 11(3), 304-324.

Trust, T., Maloy, R. W., \& Edwards, S. (2018). Learning through making: Emerging and expanding designs for college classes. TechTrends: Linking Research and Practice to Improve Learning, 62(1), 19-28.

Tsai, C., Shen, P., Chiang, Y., \& Lin, C. (2017). How to solve students' problems in a flipped classroom: A quasi-experimental approach. Universal Access in the Information Society, 16, 225-233.

Tucker, B. (2012). The flipped classroom: Online instruction at home frees class time for learning. Education Next, 12(1). Retrieved from http://educationnext.org/the-flipped-classroom/.

Turan, Z., \& Akdag-Cimen, B. (2020). Flipped classroom in English language teaching: A systematic review. Computer Assisted Language Learning, 33(5-6), 590-606. https://doi.org/10.1080/09588 221.2019.1584117.

Van Ments, M. (1999). The effective use of role-play: Practical techniques for improving learning. London: Kogan Page.

Voronina, M. V., Moroz, O. N., Sudarikov, A. E., Rakhimzhanova, M. B., \& Muratbakeev, E. K. (2017). Systematic review and results of the experiment of a flipped learning model for the courses of descriptive geometry, engineering and computer graphics, computer geometry. Eurasia Journal of Mathematics, Science and Technology Education, 13(8), 4831-4845. https://doi.org/10.12973/ eurasia.2017.00967a.

White, B., \& Frederiksen, J. (1998). Inquiry, modelling and metacognition: Making science accessible to all students. Cognition and Instruction, 16(1), 3-118.

Winter, J. W. (2018). Analysis of knowledge construction during group space activities in a flipped learning course. Journal of Computer Assisted Learning, 34, 720-730.

Wu, W.-C.V., Hsieh, J. S. C., \& Yang, J. C. (2017). Creating an online learning community in a flipped classroom to enhance EFL learners' oral proficiency. Educational Technology \& Society, 20(2), $142-157$.

Yildiz-Durak, H. (2018). Flipped learning readiness in teaching programming in middle schools: Modelling its relation to various variables. Journal Computer Assisted Learning, 34(1), 939-959.

Zainuddin, Z., \& Halili, S. H. (2016). Flipped classroom research and trends from different fields of study. International Review of Research in Open and Distributed Learning, 17(3), 313-340.

Zainuddin, Z., Haruna, H., Li, X., Zhang, Y., \& Chu, S. K. W. (2019a). A systematic review of flipped classroom empirical evidence from different fields: What are the gaps and future trends? On the Horizon. https://doi.org/10.1108/OTH-09-2018-0027.

Zainuddin, Z., Zhang, Y., Li, X., Chu, S. K. W., Idris, S., \& Keumala, C. M. (2019b). Research trends in flipped classroom empirical evidence from 2017 to 2018: A content analysis. Interactive Technology and Smart Education, 16(3), 255-277.

Zeybek, G. (2020). Flipped learning. In Ş Orakc1 (Ed.), Paradigm shifts in 21st century teaching and learning (pp. 158-180). Hershey: IGI Global.

Zhan, Y., So, W. W. M., \& Cheng, I. N. Y. (2017). Students' beliefs and experiences of interdisciplinary learning. Asia Pacific Journal of Education, 37(3), 375-388.

Zhonggen, Y., \& Liheng, Y. (2017). Correlations between learners' initial EFL proficiency and variables of clicker-aided flipped EFL class. Education and Information Technologies, 22(4), 1587-1603. 
Zou, D. (2020). Gamified flipped EFL classroom for primary education: Student and teacher perceptions. Journal of Computers in Education. https://doi.org/10.1007/s40692-020-00153-w.

Zou, D., Luo, S., Xie, H., \& Hwang, G. J. (2020). A systematic review of research on flipped language classrooms: Theoretical foundations, learning activities, tools, research topics and findings. Computer Assisted Language Learning. https://doi.org/10.1080/09588221.2020.1839502.

Publisher's Note Springer Nature remains neutral with regard to jurisdictional claims in published maps and institutional affiliations.

Bengi Birgili is a research assistant in the Department of Mathematics and Science Education, MEF University, Istanbul, Turkey, and a PhD candidate in the Department of Educational Sciences, Curriculum and Instruction Program, Middle East Technical University, Ankara, Turkey. In January 2019, she completed the Flipped Learning 3.0 Higher Education Certification Level-I offered by the FLGI.

Fatma Nevra Seggie is a professor in the Department of Educational Sciences, Boğaziçi University, Istanbul, Turkey. She received her PhD from the Higher, Adult and Lifelong Education Program at the Department of Education Administration, Michigan State University, USA. Her research areas include higher education policy, leadership, and qualitative research methods.

Ebru Oğuz is a professor in the Department of Educational Sciences, Mimar Sinan Fine Arts University, Istanbul, Turkey. Her research areas include education management and her interests lie in teacher training, learning theory, and organizational behaviour. 